\title{
FURTHER NOTES ON THE BIONOMICS OF TABANUS DITAENIATUS, MACQ., AND TABANUS TAENIOLA, P. DE B.
}

\author{
By Harold H. King, F.L.S., F.E.S. \\ (Government Entomologist, Anglo-Egyptian Sudan; Wellcome \\ Tropical Research Laboratories, Khartoum.)
}

(Plate XXVI.)

In 1909, the writer collected egg-masses of the seroot Tabanus taeniola, P. de B., and reared some of the resulting larvae to approaching maturity, but failed to obtain the pupa. The following year he took a number of immature larvae of Tabanus ditaeniatus, Macq., and reared them to the adult stage. The various stages in the life-cycles of these two Tabanids, with the exception of the pupa of the former and the egg-mass of the latter species, were figured and described in this Bulletin.* The puparium of $T$. taeniola and egg-masses of $T$. ditaeniatus which are here figured and described were obtained during the summer of 1913.

\section{Tabanus taeniola, P. de B.}

A nearly mature larva of this species was taken in wet soil at the edge of Khor Barboy, near Tonga, on the White Nile, on 20th June. It fed readily on earthworms till about 25th July, when it appeared to be mature. On 8th August it was found to have pupated; the eyes were coloured, but the rest of the pupa was yellowishwhite. Later, the wings and other appendages darkened, and finally the abdominal markings of the adult could be distinguished. An adult male emerged on 19th August.

Pupa (Plate xxvi. figs. 3-5).-Length, $21 \mathrm{~mm}$. Colour yellowish, thoracic tubercles and abdominal spiracles tinged with brown, the former bearing hairs. On the posterior third of each of the second to the seventh abdominal segments, inclusive, is a ring of backwardly projecting spines, shortest on the second segment and longest on the seventh, the spines yellowish, the ridge from which they arise chestnut-brown. The eighth segment terminates in a coronet of six teeth, chestnut-brown in colour, darker at the tips, approximately equal in size, arranged in a circle, the lateral teeth nearer to the dorsal than to the ventral teeth. Ventrally placed to this coronet. is a transverse row of tiny teeth and dorso-laterally situated on either side is a comb of five teeth, the central ones being the longest and slightly longer than those on the ventral row.

\section{Tabanus ditaeniatus, Macq.}

The egg-masses (Plate xxvi, figs. 1, 2) of this Tabanid were plentiful on grass growing in rain pools in the vicinity of Khor Barboy and at the junction of Khor Felus and the Sobat River. In shape they are very variable, some being long and narrow, others short and broad. Of the specimens collected the longest measured $20.5 \mathrm{~mm}$. by $3 \mathrm{~mm}$. and the shortest $8.5 \mathrm{~mm}$. by $4 \mathrm{~mm}$. The eggs are not covered with a secretion as are those of $T$. biguttatus, Wied. When freshly deposited the egg-mass is probably white to yellowish-white in colour, but all those taken varied from light to dark brown. 
The act of oviposition was not witnessed. The time occupied from the hatching of the egg to the emergence of the adult varied considerably. From an egg-mass which hatched on 24th June the first adult was obtained on 2nd November; while from another egg-mass which hatched on 25th July an adult was obtained on 11th September.

Of the egg-masses collected at Khor Barboy many were parasitised by an undetermined species of hymenopteron-probably a Telenomus.

Egg.-Length about $1.25 \mathrm{~mm}$., of the typical Tabanid shape. As the embryo develops the ends of the egg darken, giving the egg-mass when viewed from a distance a general dark appearance. 